\title{
The Lure of the Shore: Authenticity, Spectacle, and the Wreck of the St. Paul
}

\author{
Jamin Wells ${ }^{1}$
}

\begin{abstract}
This paper investigates the spectacle of shipwreck and marine salvage through the wreck of the transatlantic passenger liner St. Paul near Long Branch, New Jersey in 1896. As a dangerous ship trap, the New Jersey shore witnessed many shipwrecks. By the late nineteenth century, the region's extensive infrastructure facilitated the massive crowds that turned coastal wrecks into national spectacles. Businesses and entrepreneurs commodified these spectacles, exploiting fin-de-siècle America's fascination with the maritime world, technology, and "authentic" experiences. Commodification ultimately undermined spectators' search for authenticity, and successful salvage only reaffirmed the faith in American modernity that the wreck had challenged. Yet their sustained popularity during this period suggests that shipwreck spectacles fulfilled some of their promise. As a representative example, the St. Paul wreck demonstrates how shipwreck spectacles were an essential element of the lure of the shore in turn-of-thecentury America.
\end{abstract}

On a stormy night in January 1896, one of the newest and largest transatlantic passenger liners ran aground on its final approach to the port of New York. The bump was so slight that few aboard the St. Paul realized they had hit the New Jersey shore. As one passenger later admitted, "I turned over and went back to sleep." 2 Though the St. Paul was not in any immediate danger, its owners acted quickly to free the stranded liner. Salvage vessels dispatched from New York, Delaware, and Virginia raced to the scene. As passengers and their luggage were rescued from the wreck, crowds of spectators swarmed the shore to witness the sublime scene. ${ }^{3}$

For ten days the massive steamship loomed just a few hundred yards from Long Branch, New Jersey's famous Iron Pier. During that time, scores of professional marine salvors, known as wreckers, manned the fleet of tugboats, derricks, and barges that labored to save the fourth largest passenger liner in the world [Figure 1]. Tens of thousands of urbanites from New York City and Philadelphia, as well as an untold number of New Jerseyans, traveled to Long Branch to experience the spectacle of shipwreck and salvage. The spectacle along the beach and offshore became a sensationalized and entertaining public display that lured a captive audience. Railroads offered special direct trains and local businessmen opened boarded-up hotels and restaurants to serve the crowds that flocked to the St. Paul. Interest in the shipwreck extended far beyond the confines of Long Branch. Newspapers across the country published daily updates of the shipwreck, the salvage effort, and the ever-growing throngs of spectators. Illustrated articles appeared in major periodicals including Harper's Weekly, Leslie's Weekly, and Scientific American. And an eclectic mix of boosters, commentators, and humorists seized upon the example of the wreck to bolster an argument for "necessary" maritime improvements, critique American society, or make an easy joke.

\footnotetext{
${ }^{1}$ Hagley Fellow, University of Delaware.

2 "Passengers Call It a Race," New York Times, January 26, 1896.

${ }^{3}$ Ibid; "Capt. Jamison Makes Report," New York Tribune, February 4, 1896; Transcript of Record, 52-54, 72-73, 87, Case Number 909 Israel J. Merritt et al. v. The Steamship "St. Paul."; Case Files; U.S. Court of Appeals for the Second Circuit; Records of the United States Courts of Appeals, Record Group 276; National Archives and Records Administration--National Archives at New York.
} 


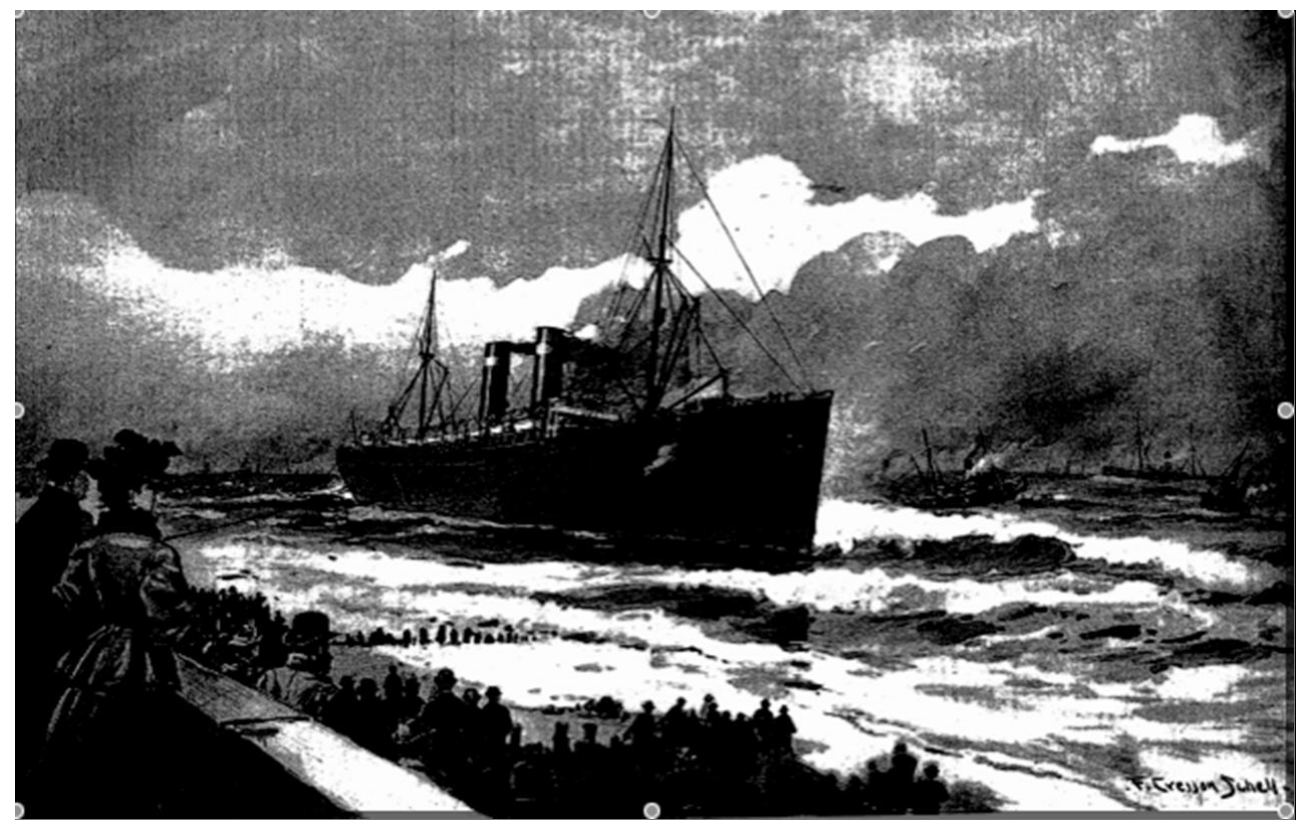

Figure 1: F. Cresson Schell, The American Line Steamship "St. Paul" Ashore off Long Branch, Leslie's Weekly, February 6, 1896.

By all appearances - the scale of the salvage effort, the extent of the media attention, and the size of the crowds - the St. Paul accident was extraordinary. But shipwreck, salvage, and spectacle were not exceptional during the late-nineteenth century. By the time the St. Paul went ashore, shipwreck events had become relatively safe, almost routine affairs. They remained a necessary, if unfortunate, consequence of commerce in a burgeoning capitalist society dependent on waterborne transportation. Yet for many, shipwrecks were also opportunities. In an increasingly legible, connected, and integrated coastal realm, savvy entrepreneurs and established businesspeople commodified coastal shipwrecks, turning frequent catastrophes into mass spectacles. Shipwreck spectacles were one way in which the sea, shore, and disaster were domesticated and commercialized, and they forged links between the littoral, mass culture, and the evolving technologies of turn-of-the-century America.

When the St. Paul wrecked, shipwrecks spoke to some of the central concerns of the age. Gazing upon or reading about wrecks fed into fin-de-siècle America's fascination with the maritime world and technology, what historian David Nye terms the "technological sublime." 4 Similarly, shipwrecks (disasters many saw as opportunities) became significant touchstones as narratives of rebirth and regeneration decisively shaped private sentiment and public discourse and as Americans routinely sought out sublime scenes of "authentic" destruction. ${ }^{5}$ Shipwrecks on the New Jersey shore routinely drew thousands of spectators and garnered sustained attention in national media outlets. High visibility and wide appeal produced mass spectacles, which

\footnotetext{
${ }^{4}$ David E. Nye, American Technological Sublime (Cambridge: MIT Press, 1994).

5 Jackson Lears, Rebirth of a Nation: The Making of Modern America, 1877-1920 (New York: Harper Collins, 2009).
} 
ironically undermined many spectators' pursuit of an authentic experience. Still, the frequency and magnitude of shipwreck spectacles suggests that they fulfilled a widespread desire to escape - if only temporarily — the quotidian details of modern life.

Shipwrecks like the St. Paul suggested the vulnerability of human mastery of the world and brought into question the perfectibility of technology. But even as shipwrecks became mass spectacles, no master shipwreck narrative developed-different groups continued to tell different narratives depending on who they were, where they were, what they knew, how they knew it, and what their motives were. For some, shipwrecks challenged unbridled confidence in material progress, technological mastery, and American exceptionalism, reinforcing their ambivalence with modernity. For others, shipwrecks conjured up narratives of heroic surfmen, beneficent bureaucracy, technological efficacy, and American humanitarianism. Successful salvage only reaffirmed those beliefs. Hotly debated at the moment, memory of the St. Paul, like that of many coastal shipwrecks, faded fast in a modern world always looking for the next media event.

\section{The Shipwreck and Salvage of the St. Paul}

The St. Paul was less than a year old when it ran aground off Long Branch in 1896. Six days before the accident, it had departed Southampton, England with 260 passengers including a Russian prince, a former U.S. Congressman, and more than 120 immigrants heading to cities across the United States. The beginning of the voyage offered smooth sailing but a succession of storms marred its final three days. On the last morning, a rival British liner, the Campania, fell in with the St. Paul and the two raced toward New York. As one passenger later described, "A gale

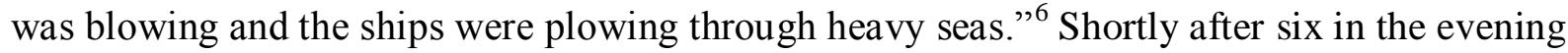
the liners steamed into fog. Onward they raced through the night, the fog thickening as they neared the American shore.

Approaching the entrance to the port of New York from the Atlantic Ocean has always been a complicated feat of navigation - to the west lie the shifting sandbars off New Jersey; to the northeast, the wreck-strewn Long Island coast. By the end of the nineteenth century, the dangers of the approach were enshrined in popular folklore and codified in government publications. The 1894 United States Coast Pilot, a specialized government publication for mariners, issued a stern warning: "In thick or foggy weather, when the ship's reckoning indicates that she is near the Jersey coast, great care should be taken to make frequent and accurate soundings with an armed lead ... [if a mariner] has reason to believe he is too near the coast, [he] should put the ship's head offshore and stand off."7 Popular wisdom held that the northern New Jersey coast was a

\footnotetext{
6 “Passengers Call It a Race," New York Times, January 26, 1896; “Customs List of Passengers” for St. Paul, 4 February 1896, Ancestry.com, New York Passenger Lists, 1820-1957 http://content.ancestrylibrary.com (accessed March 13, 2009). For an overview of the St. Paul shipwreck and salvage see: William Henry Flayhart III, The American Line, 1871-1902 (New York: W.W. Norton \& Company, 2000), 225-246; and Flayhart, Perils of the Atlantic: Steamship Disasters 1850 to Present (New York, W.W. Norton: 2003), 164-184.

${ }^{7}$ Treasury Department, United States Coast Pilot: Part 5: From New York to Chesapeake Bay Entrance, first ed. (Washington: GPO, 1894), 29.
} 
"graveyard" with a "bad reputation," what mariners and underwater archaeologists call "ship traps." 8

Dangers certainly remained, but the New Jersey coastline (as well as much of the American shore) was ringed in a dense web of institutions that guided navigators, identified vessels, reported disasters, and rescued life and property. Five lighthouses and two light-vessels offered visible markers for mariners on the otherwise featureless terrain between Montauk, Long Island and Cape May, New Jersey. A handful of fog signals rang with little effect the night the St. Paul approached New York. United States Life-Saving Service (USLSS) Stations, located every ten miles, maintained patrols along the coast from the beginning of August through the end of May to locate and assist vessels in distress. Strategically located wind signal stations, operated by the United States Weather Bureau, displayed flags indicating weather predictions "for the benefit of mariners." And four seacoast telegraph stations, operated by the Western Union Telegraph Company, reported passing vessels to the New York Maritime Exchange, a clearinghouse for commercial news. Finally, a loose network of fishermen and other coastal residents earned extra income reporting maritime causalities to New York wrecking companies. ${ }^{9}$

Well aware of the hazards in approaching the port of New York, Captain John Clark Jamison slowed the St. Paul as it neared the coastline. Jamison was a respected mariner with over twenty years of "honorable" service on transatlantic passengers. ${ }^{10}$ But the combination of dense fog, windy conditions, strong currents, and crude navigation techniques foiled his otherwise cautious approach. The St. Paul ran ashore off "the Branch" a little before two in the morning on Saturday, January 25, initiating a well-oiled rescue and response effort.

USLLS surfman Charles Sexton discovered the stranded liner shortly after it ran aground on his midnight to 4 a.m. watch. After signaling the St. Paul, he hurried back to the Long Branch LifeSaving Station and roused the seven-man crew. They carted the "wrecking apparatus" to the liner and sent the first shot across the vessel (no small feat). ${ }^{11}$ Being in no immediate danger, Captain Jamison signaled the life-saving crews that all would remain on board the St. Paul until the morning. His first message ashore was directed to the New York Maritime Exchange. The Maritime Exchange, what a contemporary described as "the marine sensorium of the Western Hemisphere," served as a communications hub, forwarding the news to the liner's owners, insurers, and other interested parties, including the Merritt and Chapman wrecking companies. ${ }^{12}$ The Merritt organization also received news of the St. Paul from Long Branch fisherman Nelson Lockwood within a half hour of it going ashore. ${ }^{13}$ The USLLS crews spent the early morning

\footnotetext{
${ }^{8}$ For example see: "Big St. Paul Runs Aground," New York Herald, January 26, 1896; "St. Paul Hard Aground," The Sun [New York], January 26, 1896; Jeannette Rattray, Perils of the Port of New York: Maritime Disasters from Sandy Hook to Execution Rocks (New York: Dodd, Mead, 1973).

${ }^{9}$ Treasury Department, United States Coast Pilot: Part 5, 10-22; Treasury Department, United States Coast Pilot: Atlantic Coast Part IV: From Point Judith to New York, $3^{\text {rd }}$ edition (Washington: GPO, 1899): 10-21. Robert D. MacMillen, Black Horse of the Sea (New York: Joseph D. McGuire, 1929).

${ }^{10}$ Flayhart, American Line, 145, 233; “Capt. John Clark Jamison,” New York Times, January 26, 1896; “The St. Paul Report," New York Tribune, February 20, 1896.

${ }^{11}$ Sumner I. Kimball, Annual Report of the Operations of the United States Life-Saving Service for the Fiscal Year Ending June 30, 1896 (Washington: GPO, 1897), 136.

${ }^{12}$ Richard Wheatley, “The New York Maritime Exchange,” Harper's Magazine (April 1890): 758.

${ }^{13}$ Transcript of Record, 195-204; RG 276; NARA NY.
} 
hours ferrying passengers' dispatches ashore and to the nearby telegraph office. From multiple sources, then, news of the stranding reached New York City and beyond.

A little after dawn, a veritable fleet of specialized salvage vessels known as wrecking steamers reached the St. Paul from New York after a daring three-hour run through thick fog. ${ }^{14}$ As word spread, steamers from Delaware and Virginia also headed toward Long Branch. Within twentyfour hours, a significant part of the country's wrecking apparatus had arrived on the scene. ${ }^{15}$ Newspaper reporters caught the morning train down the Jersey shore. And as wreckers hastened to free the liner, afternoon dailies from Boston, Massachusetts, to Santa Fe, New Mexico, published front-page stories about the accident based on, as one local writer quipped, "hearsay and supposition." Yet all the papers had a relatively sanguine opinion of the St. Paul's fate. ${ }^{16}$

By the 1890s, the region's once ad hoc wrecking industry had evolved into a consolidated, professional, and remarkably proficient corporate enterprise. ${ }^{17}$ Unparalleled opportunities, profits, and experience spurred New York's wrecking companies, making them among the best in the world. Hours after the St. Paul ran ashore, the New York Sun proclaimed "the removal of stranded ships on a beach like Jersey's has been reduced to an absolute science." 18 Still, the potential for failure - and the dramatic - remained. The USLLS reported twenty deaths related to shipwrecks in 1896, 770 since it began counting in $1871 .{ }^{19}$ Of 134 vessels that wrecked off the northern New Jersey coast between 1880 and 1896, only 72 were fully recovered. ${ }^{20}$ Wreckers probably stripped the remaining vessels and abandoned the hulks to a sublime landscape of twisted metal and rotting wood. Little wonder then that Israel Merritt gave a "dismal smile" to a reporter who asked what the chances where for salvaging the liner. ${ }^{21}$

Curious spectators began to descend on Long Branch less than six hours after the St. Paul ran aground. A local resident described the scene at first light: "She looked like a mountain, and the green lights gave her a ghostly, gruesome look." ${ }^{22}$ Men, women, and children travelled by train, carriage, and foot to the Branch. By noon, thousands were standing along the bulkhead closest to the liner. There were so many people that one reporter described the beach as "made black by the moving concourse." 23 Offshore, the St. Paul rocked in the heavy seas as more than a dozen salvage vessels endeavored to rescue it. By the New York Tribune's account,

\footnotetext{
${ }^{14}$ Transcript of Record, 59; 909; RG 276; NARA NY.

${ }^{15}$ This was the assessment of Judge Brown, who presided over the ensuing salvage case: The St. Paul, 82 F. 104, Lexis 68 [D.C, S.D NY, 1897].

${ }^{16}$ Monmouth Democrat [Freehold, NJ], January 30 1896; “Off Long Branch,” Boston Daily Journal, January 25, 1896; “The St. Paul Ashore," Kansas City Star, January 25, 1896; “Liner St. Paul in Trouble," Santa Fe New Mexican, January 25, 1896; "Rammed the U.S.," Minneapolis Journal, January 25, 1896. On general tone of reports see also: "St. Paul, Speeding in a Fog, Goes Aground," New York Times, January 26, 1896.

${ }^{17}$ Dennis M. Powers, Taking the Sea: Perilous Waters, Sunken Ships, and the True Story of the Legendary Wrecker Captains (New York: Amacom, 2009); Jamin Wells, "Professionalization and Cultural Perceptions of Marine Salvage, 1850-1950," Northern Mariner 17, no. 2 (2007): 7-16.

18 “St. Paul Hard Aground," The Sun [New York], January 26, 1896.

${ }^{19}$ Kimball, Annual Reports 1896, 14, 19.

${ }^{20}$ Transcript of Record, 120; 909; RG 276; NARA NY.

21 "St. Paul, Speeding in a fog, Goes Aground," New York Times, January 26, 1896.

22 "Crowds Watch the Big Ship," New York Tribune, January 26, 1896.

23 "St. Paul, Speeding in a Fog, Goes Aground," New York Times, January 26, 1896.
} 
At 3 o'clock it bore a decidedly retrousse appearance, and wagged backward and forward under the impetus of the arriving and departing swells[,] which flirted with it and threw foam over it as the wind blew it and caught the spray up in giant handfuls and cast it high up in the air and washed the black sides of the helpless monster till they glistened in the half-sunshine of the afternoon.

While the scene offshore may have been dramatic, the scene on the beach soon "drifted into a sort of pleasure party." 24 The sound of the crowd's mirth competing with the crash of the breakers. The USLSS finished transferring the last of the passengers and mail by 5 p.m., returning to their station after more than 24 hours of continuous labor. By sunset most of the spectators had departed, the seas had calmed, and the wreckers had prepared for a major rescue effort during the next high tide. A few hundred spectators lingered along the bulkhead opposite the Grand View Hotel "gazing at the helpless vessel" lighted stem to stern with thousands of incandescent bulbs. An observer described the radiant display as "one of the most beautiful sights that has ever been seen here." 25 Artist M. J. Burns captured the sublime scene for Harper's Weekly readers, allowing them to take part in the spectacle even if they could not physically be present [Figure 2]. ${ }^{26}$

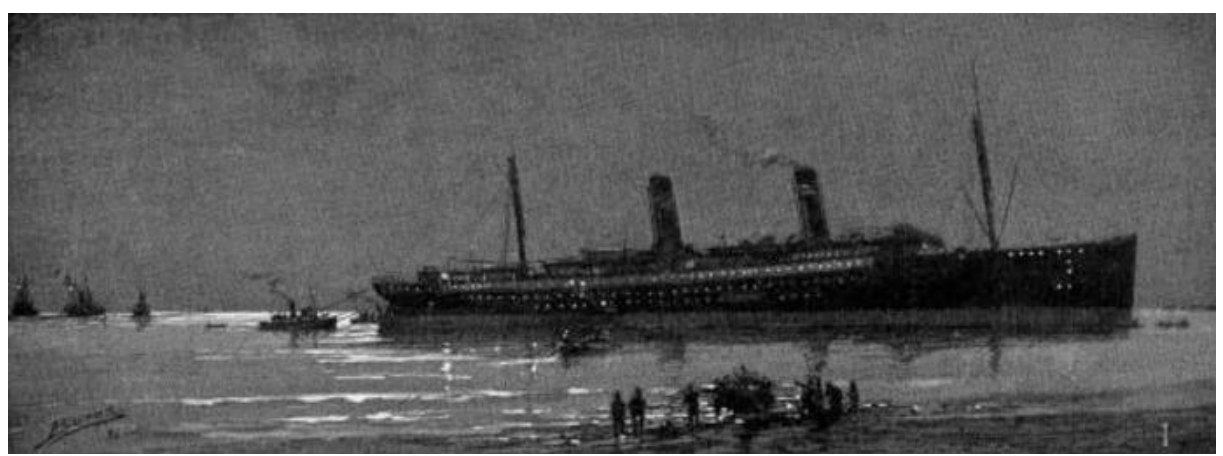

Figure 2: M. J. Burns, As She Lay on the Evening of January $30^{\text {th }}$, Harpers Weekly, February 8 , 1896.

On the second morning, Sunday newspapers across the country published accounts of the shipwreck, the salvage effort, and the swelling crowds gleaned from the Associated Press wire reports. Headlines in the St. Louis Republic, The San Francisco Call, Omaha's Sunday WorldHerald, and Chicago's Sunday Inter Ocean emphasized the St. Paul's race with the Campania, which had also run aground before backing off under its own engine power. ${ }^{27}$ Boise's Idaho Statesman, Lexington, Kentucky's Morning Herald, and dozens of other papers ran headlines declaring the St. Paul "stuck," "stranded," and "ashore.” Even London's Sunday Times published

24 “The St. Paul Aground,” New York Tribune, January 26, 1896.

25 "St. Paul, Speeding in a Fog, Goes Aground," New York Times, January 26, 1896; "Big St. Paul Runs Aground," New York Herald, January 26, 1896.

26 "The Stranding of the American Liner "St. Paul" on the New Jersey Coast, near Long Branch: From Drawings by M. J. Burns and Photographs," Harper's Weekly, February 8, 1896, 125.

27 "The St. Paul is Ashore Off Long Branch: Raced with the Campania Until Within a Few Miles of Land," St. Louis Republic, January 26, 1896; "Grounding of the St. Paul," The San Francisco Call, January 26, 1896; "Race on the Ocean," Sunday World-Herald [Omaha], January 26, 1896; "Many Lives in Peril," Sunday Inter Ocean [Chicago], January 26, 1896. 
a brief. ${ }^{28}$ The Knoxville Journal offered what might have been the day's most perceptive headline-_"Some Excitement Over the Stranded American Liner St. Paul."

This newspaper coverage took place during a watershed moment in the history of the American press. One scholar has gone so far to argue that 1897 was the "year that defined American journalism." ${ }^{29}$ Newspapers had become a "big business" more important than ever in most American's daily lives. Shipwrecks, like other disasters, were frequently subjects for the highly competitive, profit-orientated news industry. Circulation skyrocketed as national and international news increasingly displaced local stories. Papers were longer and larger, filled with more images, features, and editorials. The Sunday papers that trumpeted the St. Paul's predicament had only recently become commonplace, and the newspaper accounts of the St. Paul shipwreck reflected the sensationalist, one-upmanship and media-created pseudo-events that would characterize yellow journalism in the years to come. ${ }^{30}$

The St. Paul shipwreck became a spectacle in print and in person. On the day it went ashore, more than 10,000 people traveled to Long Branch to see the imperiled vessel [Figure 3]. The scene, reported the New York Times, "resembled a country fair." Farmers came from more than twenty miles away. Fashionably dressed visitors arrived on trains from New York City and Philadelphia to stroll or bicycle Ocean Avenue, the resort's main thoroughfare. Thousands more sat on the cold, dark sand and frequented the many booths selling food and drink. Entrepreneurs offered unobstructed views of the wreck from hotel verandas for five or ten cents. The Branch took on the chaotic character of carnival as spectators paraded, gawked, bought, and bartered at the summer resort in the middle of winter. And "the omnipresent amateur photographer," observed one reporter, "was in all his glory, and hundreds of snap shots were taken of the crowd, the vessel, and the flotilla of tugs and lighters at sea." 31 The Philadelphia Public Ledger aptly labeled the scene "an impressive spectacle." 32

\footnotetext{
28 “Stuck on a Sand Bar," Idaho Daily Statesman [Boise], January 26, 1896; "Steamer Stranded," Morning Herald [Lexington, KT], January 26, 1896; “An Atlantic Liner Ashore,” The Sunday Times [London], January $25,1896$.

${ }^{29}$ W. Joseph Campbell, The Year that Defined American Journalism: 1897 and the Clash of Paradigms (New York: Routledge, 2006).

${ }^{30}$ Frank Luther Mott, American Journalism: A History of Newspapers in the United States through 260 years: 16901950 (New York: The MacMillian Co., 1950), 571-592.

${ }^{31}$ Lighters are barges used for the conveyance of cargo from ship to shore, or vice versa. They often had cranes or derricks on them. "St. Paul is Still Fast," New York Times, January 27, 1896.

32 "Throngs of Sightseers," [Philadelphia] Public Ledger, February 3, 1896. For a fuller description of carnival and seaside resorts see: Rob Shields, "The 'System of Pleasure': Liminality and the Carnivalesque at Brighton," Theory, Culture \& Society 7 (1990): 39-72.
} 


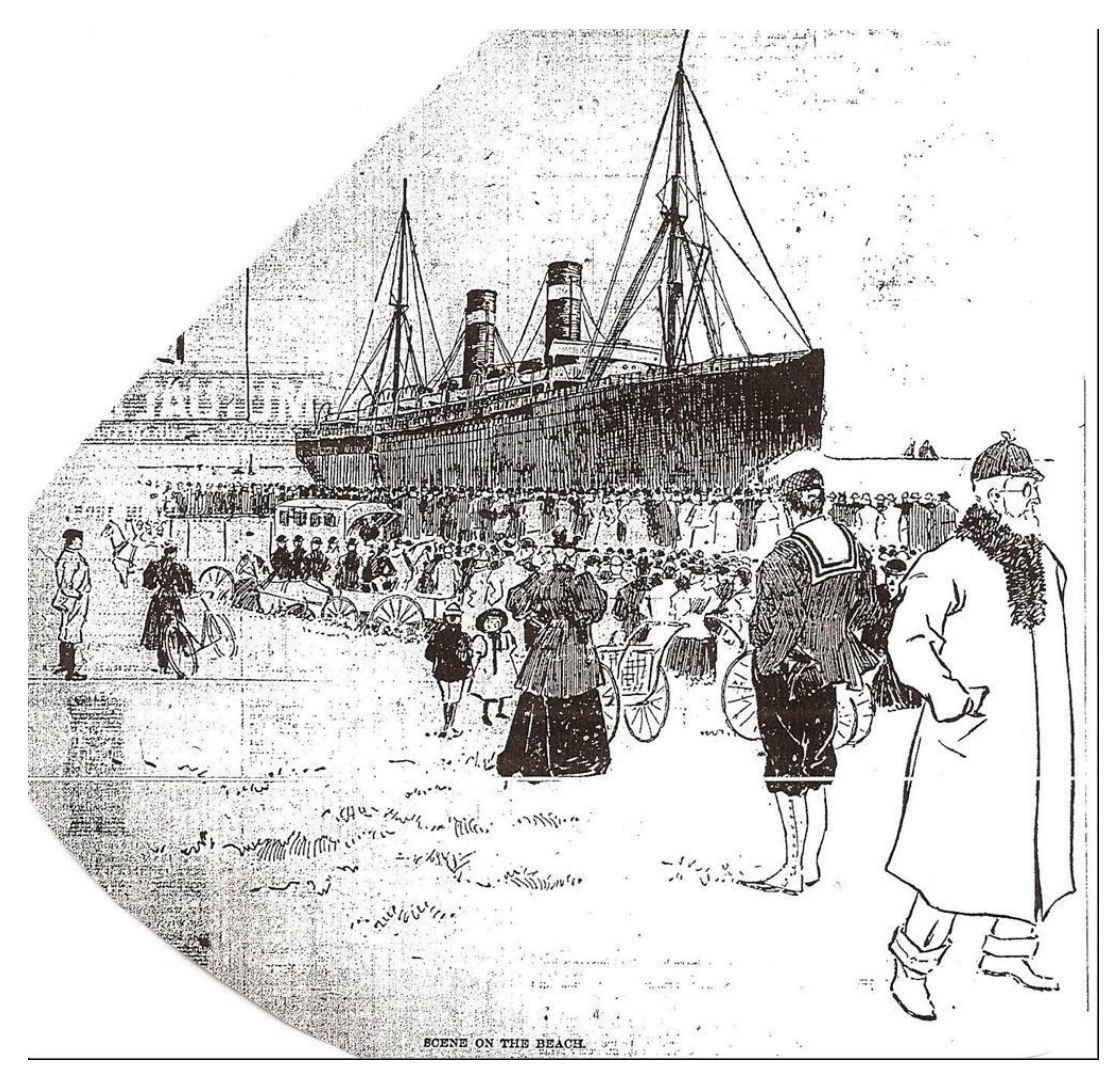

Figure 3: Scene on the Beach, New York Tribune, January 26, 1896.

By the 1890s, the cultural power of shipwrecks rested on spectacle - the large crowds, sensational representations, ritual displays, and daily performances on the beach and offshore. Modern technology, including trains, cameras, and the national media, helped to transform unfortunate accidents into impressive and entertaining displays. But shipwreck spectacles like the St. Paul were a product of the time, an expression of what historian Jackson Lears dubs the "new commercial culture of spectacle" that engulfed turn-of-the-century America. ${ }^{33}$ Shipwrecks, like lynching, popular entertainment, public amusements, and world's fairs and expositions drew cultural authority from contemporary assumptions about the undeniable veracity of visual evidence. "To see an event," writes Amy Louis Wood about this period, "was to understand its truth." But spectators did more than simply look at shipwrecks; they witnessed them. Many witnessed shipwrecks in person, even more witnessed them through published narratives and images. As witnesses, spectators conferred significance on shipwrecks, and they helped dictate the meaning of the wreck on the beach and in the media. Witnesses played a decidedly public role, one that united individuals to a larger group of fellow spectators. And the wide circulation of narratives and images of shipwrecks significantly expanded their audience, creating what was in effect an "imagined community" of shipwreck spectators. ${ }^{34}$

\footnotetext{
${ }^{33}$ Lears, Rebirth of a Nation, 250.

${ }^{34}$ I am heavily influenced by Wood's discussion and use of "spectacle" and "witnessing" in: Amy Louise Wood, Lynching and Spectacle: Witnessing Racial Violence in America, 1890-1946 (University of North Carolina Press, 2009), for quote, 4-5.
} 
Published shipwreck narratives had, by the late nineteenth century, become highly standardized. The Associated Press's news monopoly ensured that most of the country would read a terse narrative that reproduced the St. Paul spectacle on a national scale by emphasizing the crowds of spectators and sensationalizing the stakes of the wreck and salvage effort. ${ }^{35}$ Published images of the St. Paul were as standardized as the published narratives. All told, dozens of images of the St. Paul were published in local and national newspapers and periodicals. ${ }^{36}$ Most of these depictions, drawing on the iconographic ship portrait motif, offered a broadside view of the wreck surrounded by a tempestuous sea, foregrounded by the oftentimes-crowded shore. ${ }^{37}$ One notable departure from the "standard" shipwreck image was the drawing "Odd view of the St. Paul" published in the New York Herald [Figure 4]. ${ }^{38}$ In it, a fashionable group men and women chat on a busy street. Two smoke stacks and a mast rise above the roofs and the liner's dark hull is barely discernable in the distance. In "Odd view" the crowd and Long Branch-the spectacle-remained the subject though the St. Paul itself was largely absent.

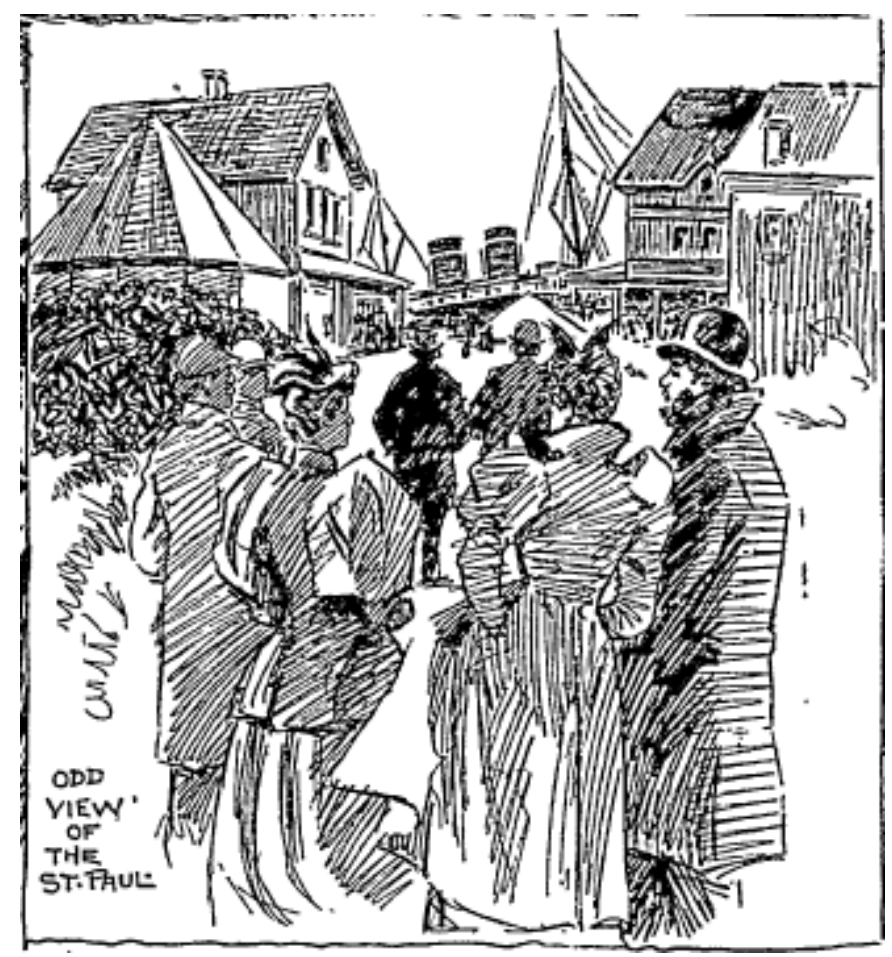

Figure 4: "Odd View of St. Paul," New York Herald, January 27, 1896.

No matter how people may have experienced the St. Paul, upstart entrepreneurs and established corporations decisively shaped the narratives and images of this national spectacle. The

\footnotetext{
${ }^{35}$ Menahem Blondheim, News on the Wires: The Telegraph and the Flow of Public Information in America, 18441897 (Cambridge: Harvard University Press, 1994).

${ }^{36}$ Images were published in all the major New York and Philadelphia newspapers. The Chicago Inter-Ocean published an image on January 26, 1896. Images also appeared in Harper's Weekly, Leslie's Weekly, and Scientific American.

${ }^{37}$ On ship portraits motif see: John Wilmerding, American Marine Painting $2^{\text {nd }}$ edition (New York: Harry N. Abrams, 1987), 82-83, 146-150; Roger B. Stein, Seascape and the American Imagination (New York: Clarkson N. Potter, 1975), 62-66.

38 “Odd View of the St. Paul," New York Herald, January 27, 1896.
} 
Associated Press was in the business of supplying the news - a salable commodity - and the content and structure of wire reports reflected its underlying profit motive. Photographers, artists and salesmen also constructed images of the St. Paul that were designed to profit from the wreck, but photographers went to the greatest lengths to craft the most marketable images. The New York Herald lampooned the "camera fiends" who were "climbing upon the tops of spiles and fencing, placing their instruments on verandas or dipping the feet of tripods in the sea" to get "the shot." 39 Their photographs were sensational, romantic images that reinforced the spectacle. Long Branch photographer Christian Fredericksen stated, "I didn't intend to take any pictures at all, because I supposed they would pull her off next day... [but then] I thought I would go down and take pictures just for fun for my customers in the summer." ${ }^{40}$ Fredericksen was one of many entrepreneurs who sold images of the stranded St. Paul. ${ }^{41}$ A stereograph distributed by one firm offered an impressive three-dimensional perspective of the massive liner [Figure 5]. ${ }^{42}$ All told, salaried and freelance artists produced dozens of drawings and engravings for newspapers and periodicals that highlighted the size of the St. Paul, the precariousness of its position, and the heroism of passengers, wreckers, and first responders.

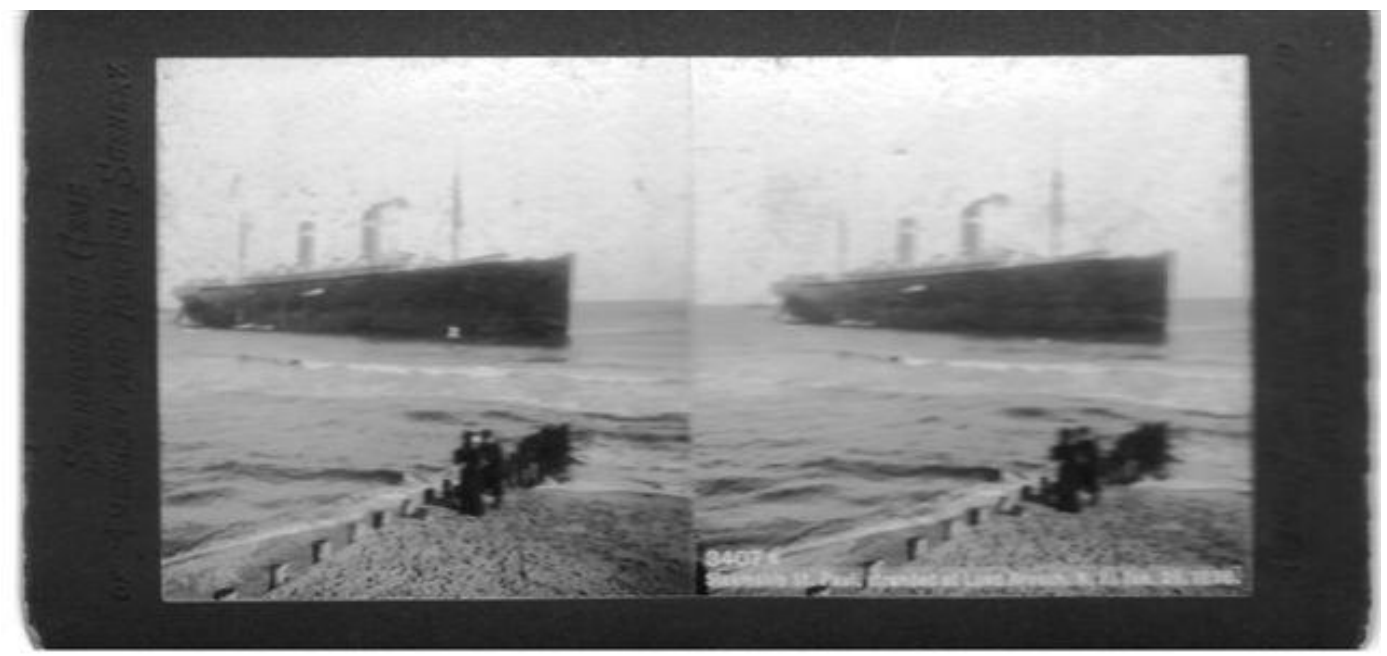

Figure 5: Stereograph of the St. Paul, Courtesy of Sharon Hazard.

In Long Branch, the scene off shore and along the beach changed little over the ensuing week. A fleet of vessels encircled the stranded liner. Wreckers unloaded cargo, repositioned anchors, and

39 "St. Paul Still Fast in the Sand," New York Herald, January 27, 1896.

${ }^{40}$ Transcript of Record, 147; 909; RG 276; NARA NY.

${ }^{41}$ In addition to Fredericksen, at least one other professional photographer, C.H. Cottrell, took many photographs of the St. Paul. Transcript of Record, 140-147; 909; RG 276; NARA NY. The renowned Pach Brothers firm likely took the photographs that served as a basis for drawings in Harper's Weekly and other major news outlets. See: Harper's Weekly, February 8, 1896, 125. The F.M. Publishing Company, publishers of Long Branch's local newspaper, advertised in local newspapers: "Pictures of the St. Paul: We will send by mail, post paid, for ten cents in stamps one handsome half tone photograph of the Steamer St. Paul. Size 9x12, suitable for framing." The Freehold Transcript [Freehold, NJ], February 7 and 14, 1896; The Red Bank Register [Red Bank, NJ], February 5 and 26, 1896.

Unfortunately, I have not located any extent copies of these images. See also: Throngs of Sightseers," Public Ledger [Philadelphia], February 3, 1896.

${ }^{42}$ I owe a debt of gratitude to Long Branch historian Sharon Hazard for sharing this stereoscope of the St. Paul from her personal collection. 
pulled the St. Paul with tugboats, yet they moved it less than seventy feet. Unseasonably calm weather hindered the salvage effort. As the wreckers explained: "We always need a sea to help get a ship off" because if "we get a little roll on the ship [from wind and waves] there is no trouble. $"{ }^{43}$ But for a week there was no wind or waves to help rock the St. Paul off the beach. Despite the lack of progress with the salvage, large crowds continued to flock to Ocean Avenue. For those unable to make the journey, reporters waxed eloquently (if sensationally) about the picturesque sea and sky that framed the spectacle, describing the St. Paul as an "impressive sight," "helpless monster," "magnificent steamship," "stately vessel," and "monster ship.,"44

Meanwhile, the accident and salvage efforts served as a lightning rod for contemporaries, gathering attention and inspiring an eclectic group of promoters to use the event to showcase a cause or bolster an argument. Vernon Brown, president of the New York Maritime Exchange, invoked the shipwreck to support the organization's lobby for federal improvements to the port of New York. Hours after the liner ran aground, Brown sent a letter calling for a government vessel to be stationed at the port to aid distressed vessels and prevent accidents. ${ }^{45}$ Six days later, Brown used a similar argument in Washington, D.C., while promoting a bill that would have provided a new aid to navigation near the entrance to New York Bay. ${ }^{46}$ William Strong, the reform mayor of New York City, referenced the St. Paul in his successful bid to erect a new, larger dry dock in Brooklyn. ${ }^{47}$ And W. H. Beehler, a lieutenant at the US Naval Hydrographic Office, used the wreck to illustrate his theory that atmospheric conditions influence the Gulf Stream. ${ }^{48}$

The St. Paul also served as fodder for humorists, dramatists, and punsters. "The St. Paul Lies Beside the Sea," a doggerel published by several papers, mocked the despair of the wreckers who "dropped a bitter tear" over their inability to free the stranded liner [Figure 6]. ${ }^{49}$ The night before the wreckers succeeded, Philadelphia's Eleventh Street Opera House premiered a skit: "The St. Paul in the Sand: or, Stuck on Jersey." The skit served as the finale for the popular Dumont's Minstrels show, one of the few regular minstrel shows that remained in the northeast by the late 1890s. It contributed to what the Philadelphia Inquirer described as the theatre's ongoing "burlesquing of current public matters in such a manner as to afford a rich entertainment of wit." "Two months after wreckers freed the St. Paul, Puck, a popular weekly humor magazine, could still reference the accident and Long Branch's notorious underground gambling industry:

\footnotetext{
${ }^{43}$ Transcript of Record, 81, 100; RG 276; NARA NY.

44 "Fast Locked in the Sand," New York Tribune, February 29, 1896; "St. Paul Moved a Short Distance," [Philadelphia] Evening Bulletin, January 29, 1896; "Big St. Paul Runs Aground," New York Herald, January 26, 1896; “The St. Paul Still Fast," New York Times, January 29, 1896.

45 “A Sea-Going Revenue Vessel Needed,” New York Tribune, January 26, 1896.

46 “A New Lightship off Fire Island," New York Times, February 2, 1896.

47 "Favors a Big Dry Dock," New York Times, February 14, 1896; "Danger Lurks for Platt and Morton," Philadelphia Inquirer, February 16, 1896; "Great Dock to Be Built," New York Times, March 12, 1896.

48 "Dangers of the Gulf Stream," New York Times, January 30, 1896; "Winds Affect Currents," New York Times, February 23, 1896.

49 “The St. Paul Lies Beside the Sea," Philadelphia Inquirer, February 4, 1896. Editorial, New York Tribune, January 31, 1896.

50 "What Was Done at the Theatres," Philadelphia Inquirer, February 4, 1896; "Eleventh Street Opera House," Philadelphia Inquirer, February 9, 1896. Frank Dumont, The Witmark Amateur Minstrel Guide and Burnt Cork Encyclopedia (London: M. Witmark \& Sons, 1899), 5-7.
} 
Lea: I see where the St. Paul's going ashore at Long Branch cost the American Line one hundred and fifty thousand dollars.

Perrins: I don't doubt it! I was there myself for two weeks last summer. ${ }^{51}$

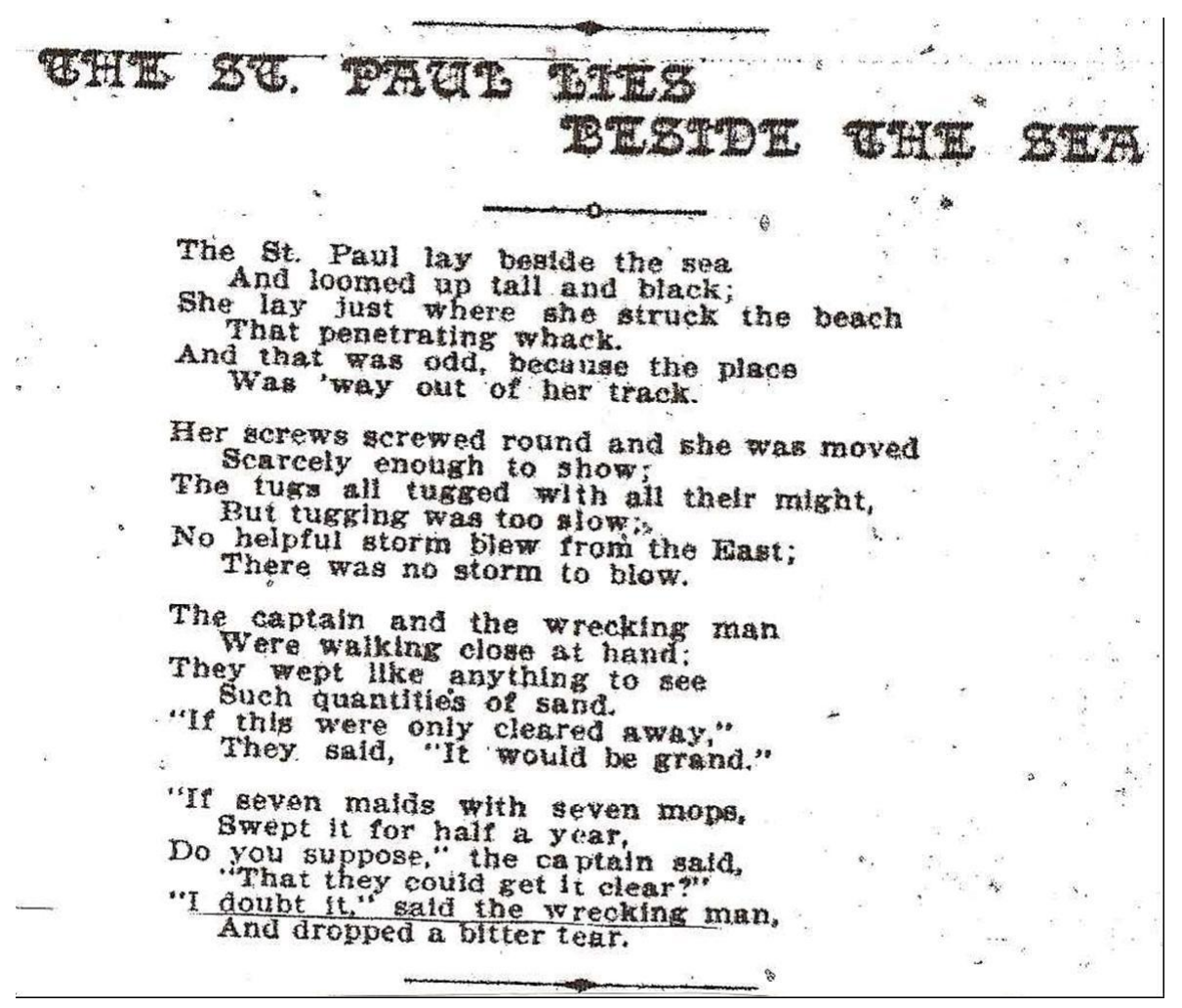

Figure 6: The St. Paul Lies Beside the Sea, Philadelphia Inquirer, February 4, 1896

Perrins's cynicism was not misplaced. Long Branch entrepreneurs had acted quickly after the St. Paul ran aground to turn disaster into profit. Local hackmen (drivers of hacks or carriages for hire) were among the first to realize the windfall generated by the seaside spectacle. On the morning of the wreck, nobody knew why so many people were getting off the train. By the afternoon, the first thing anybody heard as they left the train station was, according to one reporter, "the stentorian call of the hackman: 'Here you are! Fifteen minutes to the wreck!' " Not incidentally, fares had doubled or tripled. ${ }^{52}$ Business owners opened hotels and restaurants that had been closed since fall. Stands selling lemonade, cigars, popcorn, and liquor appeared "like magic." Boys sold photographs of the stranded liner and professional crooks worked the crowds. Even local fishermen profited by charging particularly enthusiastic spectators fifty cents to be

\footnotetext{
${ }^{51}$ Puck, "Same Thing all the Year Round," April 1, 1896, 11; on gambling see: Francis H. Hardy, "Seaside Life in America," The Eclectic Magazine of Foreign Literature, January-June 1897, 37-45.

52 “Crowds Watch the Big Ship," New York Tribune, January 26, 1896; "St. Paul Still Fast in the Sand," New York Herald, January 27, 1896.
} 
rowed around the St. Paul. ${ }^{53}$ Men, women, and children piled into overcrowded vessels and went around the steamer "like some moving endless chain." 54 Just three days after the stranding, the New York Tribune could report, "From hotel men to peanut venders [sic] the Jerseymen are gathering a golden harvest." ${ }^{, 55}$ By the time the St. Paul left Long Branch commentators estimated the stranding had injected $\$ 15,000$ - equivalent to almost $\$ 400,000$ in 2008 dollars - into the summer resort's dormant economy in less than two weeks. ${ }^{56}$

Not every Long Brancher profited from the St. Paul. Within two days of the wreck, owners of waterfront property near the liner were complaining of the damage done by spectators. One resident went as far as having some of the visitors arrested for trespassing on his property. Others suffered more serious losses. The St. Paul went ashore within 50 yards of a collection of codfish nets and poles. The fishermen, who owned the fishing gear and leased the spot, "warned the wreckers not to trespass, and," as one observer wryly noted, "these orders were so strictly obeyed that the nets are almost entirely demolished." ${ }^{57}$ Even for locals (who arguably profited most from the St. Paul), the narrative of the wreck resisted closure as different groups fashioned different narratives based on who they were, what they did, and how they were affected. It was no unalloyed boom for an otherwise struggling seaside resort.

The crowds occasionally overwhelmed the seasoned resort even as they contributed to its coffers. The most spectators arrived on Sunday, February 2, eight days after the shipwreck. Long Branch had prepared for several thousand, but at least 25,000 eventually arrived on their day off from work. Five thousand Philadelphians, including a large contingent of laborers from the shipyard that built the St. Paul, filled almost 100 cars on the eight trains that ran to the Branch. Four special trains ran from New York City, bringing thousands more. ${ }^{58}$ Working-class laborers mixed with middle-class families on Long Branch's winter boardwalk as blue-collar sociability met white-collar restraint. The spectacle of the St. Paul suited both groups: relatively low admission price (the price of a train ticket) and lack of language barriers drew the working class as the opportunity for didactic leisure suited middle-class sensibilities. ${ }^{59}$

Visitors comfortable with the commercialized leisure found in corner saloons and old Coney Island haunts bought and bartered on an unexpected mid-winter Sunday picnic. Newspapers disagree about whether saloonkeepers flaunted local blue codes and sold alcohol to thirsty crowds. But hucksters quickly set up a roulette wheel and shell games, and balladeers rhapsodized about the steamer's predicament. Every hotel and restaurant opened for business; many had prepared special menus. For twenty-five cents, visitors could buy clam chowder, ham

\footnotetext{
53 “Crowds at Long Branch,” New York Times, February 3, 1896; “A Great Throng Gazed at St. Paul,” Philadelphia Inquirer, January 3, 1896; "Viewed by Thousands," New York Tribune, February 3, 1896;

54 "St. Paul Still Fast in the Sand," New York Herald, January 27, 1896.

55 "Fast Locked in the Sand," New York Tribune, January 29, 1896.

${ }^{56}$ Lawrence H. Officer and Samuel H. Williamson, "Purchasing Power of Money in the United States from 1774 to 2008," MeasuringWorth, 2009, accessed January 20, 2010, http://www.measuringworth.com/ppowerus/; "St. Paul Gets Off," New York Herald, February 5, 1896.

57 “The Liner Still Helpless,” New York Tribune, January 28, 1896; “Long Branch,” New York Times, January 31 , 1896.

58 "Crowds at Long Branch," New York Times, February 3, 1896.

${ }^{59}$ On leisure during this time see: Roy Rosenzweig, Eight Hours for What We Will: Workers and Leisure in an Industrial City, 1870-1920 (Cambridge: Cambridge University Press, 1985); Cathy Peiss, Cheap Amusements: Working Women and Leisure in Turn-of-the-Century New York (Philadelphia: Temple University Press, 1986).
} 
sandwiches, or soup from one of the innumerable small stands that lined Ocean Avenue. By one in the afternoon they had all run out of food. Local grocers, butchers, bakers, and delicatessens opened, selling cakes, pies, and crackers. Prices skyrocketed until their stock also ran dry. By the late afternoon, the spectators were eager to get back on the trains after a long day at the shore. ${ }^{60}$

Railroad companies ran more than a dozen special trains from Philadelphia and New York during the eleven days that the St. Paul was ashore. The Pennsylvania Railroad charged $\$ 1.50$ for a round trip fare from Philadelphia, seventy-five cents for children under twelve. ${ }^{61}$ Indeed, the spectacle's economic boon reached far beyond Long Branch. As the New York Times eventually concluded, "While the St. Paul was ashore the residents of Long Branch and the railroads profited greatly." ${ }^{2}$ The wreckers who freed the St. Paul also profited handsomely from the St. Paul. In addition to employing hundreds of extra men, their $\$ 160,000$ salvage award-equivalent to almost $\$ 4.3$ million in 2008 dollars — was the second largest on record. ${ }^{63}$

After ten days of around-the-clock work, a favorable shift in the weather helped wreckers pull the St. Paul off Long Branch's sandbar. A building nor'easter rocked the St. Paul as four wrecking steamers dragged the liner off the beach a little before 10 a.m. on February fourth. An hour after the liner left, the last of the wrecking vessels departed, and the shore, "so long dotted with spectators, was deserted." 64 The St. Paul docked at its pier in Lower Manhattan before two that afternoon. The summer resort lost its winter drawing card. "There is an aching void in the heart of every Long Brancher to-night," editorialized a Philadelphia newspaper, "for their pet attraction, the St. Paul, instead of being on the beach, as a feast for thousands of pairs of eyes, is safely moored at her dock." ${ }^{65}$ Long Branch soon returned to the slower rhythms of a seaside resort in early February. The liner resumed service. ${ }^{66}$ And the seaside spectacle faded from memory.

\section{A Familiar and Fascinating Sight}

Long Branch's reputation for hosting fantastic spectacles was well established when the St. Paul wrecked in 1896. Since the late eighteenth century, trips to the New Jersey resort town had inevitably included high-stakes gambling, thrilling horse races, teeming beaches, and eclectic crowds. ${ }^{67}$ Prominent politicians and patent medicine millionaires mixed with gamblers,

\footnotetext{
60 “Crowds at Long Branch,” New York Times, February 3, 1896; “A Great Throng Gazed at St. Paul,” Philadelphia Inquirer, January 3, 1896; "Viewed by Thousands," New York Tribune, February 3, 1896; "The St. Paul Floated," Red Bank Register [Red Bank, NJ], February 5, 1896.

${ }^{61}$ Advertisement, [Philadelphia] Evening Bulletin, January 31, 1896.

62 “St. Paul Safely Floated," New York Times, February 5, 1896.

${ }^{63}$ Officer and Williamson, "Purchasing Power;" "Still Fast in the Sand," New York Times, February 1, 1896; The St. Paul: Merritt et al. v. The St. Paul; Same v. International Nav. Co., 82 F. 104, Lexis 68 (U.D. Dist. 1897); "Large Salvage on St. Paul," New York Times, April 24, 1898; Transcript of Record, 87, 163-168, 174-175; 909; RG 276; NARA NY.

64 “St. Paul Gets Off," New York Herald, February 5, 1896.

65 "The Scene on the Shore," Philadelphia Inquirer, February 5, 1896.

66 “St. Paul will Sail Wednesday,” New York Times, February 20, 1896; "Maritime News: By Cable,” New York Times, March 6, 1896.

${ }^{67}$ Witers' Project, Work Projects Administration, State of New Jersey, Entertaining a Nation: The Career of Long Branch, American Guide Series (Bayonne, NJ: Jersey Printing Company), 43-98; Richmond Barrett, Good Old Summer Days: Newport, Narragansett Pier, Saratoga, Long Branch, and Bar Harbor (New York: D. Appleton-
} 
confidence men, and wealthy elites during the busy summer season. Unlike other popular late nineteenth-century resorts, Long Branch continued to accommodate visitors of all social classes. ${ }^{68}$ It served as the nation's unofficial summer capital during the 1870 s and 1880 s, offering four consecutive U.S. administrations reprieve from Washington, D.C.'s heat and welcoming weekend trains filled with thou sands of working-class day-trippers from nearby cities and factory towns. By the 1890s, however, the resort was past its prime, having lost its biggest attractionthe Monmouth Park Racetrack - to Republican antigambling legislation. Despite its struggles, diverse crowds continued to visit the Branch. As late as 1897 a Life magazine writer could note "society at the Branch is like its drinks - very much mixed.",69

Shipwrecks were another prominent feature of late nineteenth-century Long Branch. In the sixteen years before the St. Paul wrecked, salvage experts counted almost 200 vessels that "went ashore on the Jersey coast" between Sandy Hook and Barnegat Light. ${ }^{70}$ At least one vessel wrecked near Long Branch each year between 1889 and 1896. Forty-six days before the St. Paul wrecked, the steamship Irrawaddy went ashore in fog not far from the Branch's famous Iron Pier. Even as wrecking tugs struggled to rescue the St. Paul, the ship Foyle wrecked just two miles north. ${ }^{71}$ Hours after the St. Paul finally docked in New York City, the British steamship Lamington met disaster less than fifty-five miles east of Long Branch. Two days later, the schooner Asenath A. Shaw went ashore 65 miles south of the resort. ${ }^{72}$ In 1897, the year after the St. Paul accident, at least three vessels wrecked within five miles of the Iron Pier. Northern New Jersey was, in short, a dangerous ship trap for transatlantic and coastal shipping at the end of the nineteenth century.

Even so, the frequency of shipwrecks near Long Branch was not uncommon for the time. A conservative tally by the United States Life-Saving Service in 1896 estimated nearly 9,000 ships had wrecked since 1871 along portions of the American coast under its ever-expanding purview. ${ }^{73}$ The number of wrecks listed in government publications the year the St. Paul ran ashore ranged from 680 to $1,313 .^{74}$ These numbers (averaging roughly two to three wrecks each day) should be read as low estimates because they represent only reported incidents; even a casual survey of contemporary newspapers affirms the extraordinary number of shipwrecked,

Century Company, 1941), 244-248; William Nelson, ed., The New Jersey Coast in Three Centuries vol. 2 (New York: Lewis Publishing Company, 1902), 50-53.

${ }^{68}$ John Sterngass, First Resorts: Pursuing Pleasure at Saratoga Springs, Newport \& Coney Island (Baltimore: Johns Hopkins University Press, 2001).

${ }^{69}$ Joseph Smith, “Life's Personally Conducted Tours: Long Branch,” Life, June 24, 1897, 532.

${ }^{70}$ This is a roughly fifty-mile stretch of coastline. Long Branch is approximately twelve miles south of Sandy Hook and thirty-eight miles north of Barnegat Light. Transcript of Record, 85-86, 120; 909; RG 276; NARA NY.

71 "Wrecks and Rescues of the Past," New York Times, January 27, 1896; “On Shrewbury Rocks," New York Tribune, January 27, 1896.

72 "Another Ship in the Sand," New York Tribune, February 6, 1896; Kimball, Annual Report 1896, 141.

${ }^{73}$ These numbers reflect the operations of the USLLS rather than the total number of wrecks off the American coastline. There were 8,982 "disasters" that occurred within the operations of the Service, which did not expand beyond the east coast to include Texas, the Great Lakes, and portions of the Pacific Coast until the 1880s and 1890s. Kimball, Annual Report 1896, 19.

${ }^{74}$ Six-hundred-and-eighty "disasters" occurred within the operations of the USLSS in the fiscal year ending on June 30, 1896. The extent of operations included 256 stations on the Atlantic, Pacific, Gulf and Lakes coasts. The larger figure, includes, "disasters to vessels which occurred on and near the coasts and on the rivers of the United States" in 1896, as tabulated in the Statistical Abstracts. Kimball, Annual Report 1896, 14; Bureau of Statistics, Statistical Abstract of the United States (1897), 392. 
stranded, or lost vessels off the American coast during this period. In the dynamic littoral hard numbers were difficult to compile, vessels disappeared, and human mastery remained at best tenuous.

While shipwrecks were familiar events for turn-of-the-century Americans, several factors distinguished the St. Paul accident. The liner was a well-known vessel at the center of national discussions about America's place in a rapidly changing world. Currier and Ives, the New York publishing firm renown for capitalizing on especially interesting, newsworthy topics, published a lithograph of the St. Paul around the time it was launched in $1895 .^{75}$ Along with its sister ship the St. Louis, the St. Paul was the first competitive American-built transatlantic passenger vessel to be launched in decades. ${ }^{76}$ The vessels' size, speed, seaworthiness, and luxury demonstrated the competency of the oft-maligned American shipbuilding industry; symbolized the efforts of American business and government to develop the country's international stature; and represented hope for a return to American maritime preeminence. ${ }^{77}$ Discussion of either vessel was infused with blind patriotism - indeed, they sailed for the American Line. After inspecting both vessels, one commentator declared: "America may [now] safely challenge the world."78 And challenge it did. On its third voyage, the St. Paul beat a British-built rival to the dock in a dramatic twenty-hour race. ${ }^{79}$ When the St. Paul wrecked, people on both sides of the Atlantic took notice. ${ }^{80}$

Interest in the St. Paul shipwreck was part of an ongoing American preoccupation with the maritime world. ${ }^{81}$ At the end of the nineteenth century, attention to the sea, shore, and shipwrecks developed as broader trends reshaped how people thought about and interacted with the sea and shore. The closing of the frontier, rising waves of immigration, the decline of the merchant marine, the growth of coastal tourism, rapid technological developments, and overseas imperial aspirations and expeditions changed America's relationship with the sea. Uncertainty reigned as America's maritime industries faced stiff international competition. Paradoxically, physical changes to turn-of-the-century ports solidified a new spatial regime that separated urban citizens from the working sea at the same time the nation began to look abroad. Isolated from working waterfronts, most people increasingly encountered the sea at one of the nation's many

\footnotetext{
${ }^{75}$ Gale Research Company, Currier and Ives: A Catalogue Raisonné (Detroit: Book Tower, 1984). For actual print: "St. Paul (Hull 278), of the American Line," Philadelphia Maritime Museum Collection (83.17.3).

${ }^{76}$ For the definitive account of the American Line see: Flayhart, American Line.

${ }^{77}$ John G. B. Hutchins, The American Merchant Industries and Public Policy, 1789-1914 (Cambridge: Harvard University Press, 1941), 533-536; Alex Roland, et. al., The Way of the Ship: America's Maritime History Reenvisioned, 1600-2000 (Hoboken, NJ: John Wiley and Sons, 2008), 209-224; Flayhart, American Line, $137-224$.

${ }^{78}$ Francis Churchill Williams, “Art in Ship-Building," Harper's Weekly, October 26, 1895, 1013; Flayhart, American Line, 171-226.

${ }^{79}$ The rival - the British-built Campania — was the same liner the St. Paul would race through the fog before wrecking off Long Branch. "A Race Between Ocean Liners," New York Tribune, December 14, 1895.

80 “An Atlantic Liner Ashore," The Sunday Times [London], January 26, 1896; "The Steamer St. Paul," The Standard [London], January 28, 1896.

${ }^{81}$ This argument complicates Helen Rozwadowski's claim that "The ocean's depths lost their firm hold on the Anglo-American cultural imagination" beginning in the 1880s. Helen M. Rozwadowski, Fathoming the Ocean: The Discovery and Exploration of the Deep Sea (Cambridge: Harvard University Press, 2005), 217. Shipwreck spectacles suggest that Rozwadowski's "cultural interest in the ocean's depths" merely shifted to the littoral, particularly the dangerous littoral. As Allen Sekula writes: "The sea returns, often in gothic guise, remembered and forgotten at the same time, always linked to death, but in a strangely disembodied way." Allan Sekula, "Between the Net and the Deep Blue Sea (Rethinking the Traffic in Photographs)," October 102 (Fall 2002), 14.
} 
coastal resorts, like Coney Island, which offered a leisure experience of the sea and shore mediated by profit and loss. Still, romanticized, fanciful notions continued to dominate popular conceptions of the sea and shore even as Americans engaged them in new and decidedly modern ways. $^{82}$

The contours of America' new relationship with the sea was reflected in American culture. Stephen Crane, Jack London, and many other sailor-writers including Morgan Robertson, Lincoln Colcord, and Thornton Hains reinvigorated American sea fiction during this period. Their adventure literature began to appear in the 1890s, elegizing the "lost glory" of the age of sail even as it tepidly embraced steam navigation. ${ }^{83}$ Around the same time, a distinct American style of marine painting matured in the work of Winslow Homer, Thomas Eakins, and Albert Pinkham Ryder. One scholar celebrates this period as the "great age" of American marine painting. For another, it marked the "end of an era." ${ }^{84}$ Either way, the country's changing relationship with the sea was reflected in the period's art and literature. Popular culture was similarly affected as a veritable maritime craze swept the country. The solo-sailing exploits of Joshua Slocum shared headlines with polar explorers, distant naval engagements, and local yacht club regattas. Discussions of America's Cup races and transatlantic passenger liners were infused with nationalist rhetoric. Closer to home, popular periodicals urged "ingenuous boys" to build boats. And by the late 1890 s, scores of films offered urban theatergoers dramatic images of sailing ships, ocean liners, harbors, storms, and shipwrecks. ${ }^{85}$

Shipwrecks in particular offered compelling images, sensational stories, and physical sites that captivated modern audiences. They were disasters and turn-of-the-century Americans "loved" disasters. Kevin Rozario argues during the late nineteenth century, American culture became a "culture of calamity." Disasters, destruction, chaos - the building blocks of modern, corporate American society - became a thrill, a fascination for Americans whose prosperity was founded on the creative destruction of capitalist development. As Rozario argues, "a society founded on

\footnotetext{
${ }^{82}$ On America's changing relationship to the sea see: Benjamin W. Labaree et al., America and the Sea: A Maritime History (Mystic, CT: Mystic Seaport, 1998), 363-475; and Roland et al., Way of the Ship, 181-263; Josef W. Knovitz, "Changing Concepts of the Sea, 1550-1950," Terrae Incognitae 11 (January 1979): 1-17; Josef W. Knovitz, "The Crises of Atlantic Port Cities, 1880-1920," Comparative Studies in Society and History 36 (April 1994): 293-318.

${ }^{83}$ Bert Bender, Sea-Brothers: The Tradition of American Sea Fiction from Moby-Dick to the Present (Philadelphia: University of Pennsylvania Press, 1988), 148.

${ }^{84}$ Wilmerding, American Marine Painting, 154; Stein, 123.

${ }^{85}$ On popular culture see: Michael F. Robinson, The Coldest Crucible: Arctic Exploration and American Culture (Chicago: University of Chicago Press, 2006); Joshua Slocum, Sailing Alone Around the World (New York: Sheridan House, 1999 [1899]); Albert B. Farnham, “A Cheap Skiff," Youth's Companion, June 21, 1894, 291; George A. Stewart, "Boats that Boys Can Build," Youth's Companion, March 7, 1895, 118; Stewart, "Boats that Boys Can Build: Part II," Youth's Companion, March 14, 1895, 128; George R. Riley, "How to Build a Bicycle Boat," The Ladies' Home Journal, August 1904, 25. Plans for building boats were also published in many of the "how-to" books published for boys during this period. See for example: Daniel C. Beard, The American Boys Handy Book (New York, 1907 [1882]), 95-131, 281-285, 389-409; Daniel C. Beard, The Jack of All Trades (New York, 1914 [1896]), 146-169; Beard, The Outdoor Handy Book (New York, 1914 [1896]), 156-221; and Maurice Thompson, ed., The Boys Book of Sports (New York, 1886), 91-99, 199-232. Examples of relevant films from 1899 include: Wreck of the Norseman, (USA, 1899); Wreck of the 'Mohican,' (USA, 1899); Wreck of the S.S. 'Paris' (USA, 1899); and The Breeches Buoy, American Mutoscope \& Biograph (USA, 1899). Imdb.com lists film titles for this period that, while incomplete, suggest the frequency of maritime topics. "1899 Films' Search," Internet Movie Database, accessed March 4, 2007, http://www.imbd.com (accessed March 4, 2007).
} 
creative destruction had to develop a cultural appreciation for annihilation." ${ }^{\circ 6}$ Shipwrecks annihilated, they created, and they were popular in fin-de-siècle America.

Further, the metaphor of the shipwreck, a well-worn rhetorical trope employed by statesmen, religious leaders, artists, and writers, continued to find wide use. As Daniel W. Lane argues, "metaphors of wrecks, wrecking, and lifesaving ... provided a vocabulary for framing personal, corporate, and national struggles" during the second half of the nineteenth century. ${ }^{87}$ But subtle changes in the meaning of that metaphor took shape as new cultural attitudes emerged alongside the development of corporate capitalism and spread of consumerism. Certainly the proliferation of representations of shipwrecks suggested, as David C. Miller argues, a widespread "loss of faith" in the American corporate enterprise during and after the Civil War. ${ }^{88}$ Yet as post-bellum shipwreck narratives increasingly focused on rescuers rather than the rescued, artists and writers proudly celebrated American's humanitarianism and ingenuity in a new genre of lifesaving narratives, which focused on the prevention shipwrecks or the application of skill and technology to rescue lives and property. Winslow Homer's The Life-Line, as Lane suggests, "implies that coastal shipwreck, while hazardous, need not have been catastrophic because American technology and skill could systematically confront and overcome peril." ${ }^{89}$ Whether they were inspiring or dispiriting, late nineteenth-century representations of shipwrecks were contested terrain that resisted narrative closure and invited multiple (often conflicting) viewpoints. In this way, shipwreck narratives pointed toward distinctly modernist modes of experience that would be characterized by unsettling ambiguity, uncertainty, and open-endedness.

Finally, in an age of spectacle, shipwrecks became spectacles. Shipwrecks had been an essential element to the lure of the shore in Western Culture since the mid-eighteenth century. ${ }^{90}$ But the transportation and communication revolutions enabled far more people to learn about and visit shipwrecks, turning a sublime or romantic sight into a mass spectacle. By the late nineteenth century, newspapers, popular periodicals, and the emergent film industry regularly detailed the danger, suffering, and spectacle of shipwrecks to national audiences. ${ }^{91}$ These highly standardized images almost always showed a crowd of spectators, marking the shipwreck as a sight worth seeing. Representations of coastal shipwrecks recreated the spectacle itself for armchair

\footnotetext{
${ }^{86}$ Kevin Rozario, The Culture of Calamity: Disaster and the Making of Modern America (Chicago: University of Chicago Press, 2007), 106, 101-132.

${ }^{87}$ Daniel W. Lane, "Nineteenth-Century American Shipwreck Narratives and National Identity" (PhD diss., University of Delaware, 2002), 228.

${ }^{88}$ David C. Miller, "Introduction," in American Iconology: New Approaches to Nineteenth-Century Art and Literature, ed. Miller (New Haven: Yale University Press, 1993), 11. See also: Miller, "The Iconology of Wrecked or Stranded Boats in Mid to Late Nineteenth-Century American Culture," in Miller, American Iconology, 186-208. ${ }^{89}$ Lane, "American Shipwreck Narratives," 194.

${ }^{90}$ Alain Corbin, Lure of the Sea: Discovery of the Seaside in the Western World, 1750-1840, trans. Jocelyn Phelps (New York: Penguin Books, 1994), 234-240. Lure of the Sea, incidentally, was the inspiration for the title of this essay.

${ }^{91}$ Representative literature includes: Stephen Crane, The Open Boat (New York, 1898); Joanna R. Nicholls, “Cooperation Between Seamen and Surfmen: an Imperative Need of the Life-Saving Service," Godey's Magazine, September 1897, 249-254; Page Milburn, “Two Shipwrecks," Zion's Herald, October 1898, 1298; J. Hooker Hamersley, "Youth's Department: Shipwreck," New York Observer and Chronicle, December 30, 1897, 923. For representative art see: Winslow Homer, The Wreck, 1896, Carnegie Museum of Art, Pittsburgh, PA; Homer, The Gulf Stream, 1899, Metropolitan Museum of Art, New York; Harrington Fitzgerald, The Wreck, 1901, Smithsonian American Art Museum, Washington, DC. On representative film shorts see note 85.
} 
spectators, enabling a national audience to see and even participate in the spectacles. The curious (and close) invariably crowded any accessible shoreline with a view of a wreck, turning shipwrecks into spectacles as much as reporters and newspaper editors did. As the New York Herald declared in 1896, "The people of New Jersey and visitors from the city let no chance slip them of seeing a steamer in distress." 92

Shipwrecks drew the attention of turn-of-the-century Americans because they were manifestations of the technological sublime, or what David Nye describes as that "essentially religious feeling" aroused by Americans' confrontation with impressive human-made objects and natural landscapes. ${ }^{93}$ Coastal shipwrecks offered compelling vistas of ships - the technological wonders of industrial America — and the sea—untrammeled wilderness. The New York Herald captured the essence of this dual sublimity off Long Branch:

There was a strength and symmetry in every line [of the St. Paul]. There were majesty and power in every curve of the black hull and towering masts... The sunlight glinted over her snow white railings and her shining brasswork. Her huge bulk, keeled over to port, gave her the look of a monster which, suddenly trapped, bends every power to be free again. Over and above her was a mantle of blue, pierced with shafts of sunlight. The sea, grey and somber, with a ripple of brightness here and there, surged about her. ${ }^{94}$

Visitors were truly awed by the display. One Philadelphian declared: "That is a great sight, but it makes me sad to look at it. Why, I see that ship lying there in my dreams." A reporter concluded that, "It was this feeling that made the crowd on the beach a rather quiet one. It stood there and gazed until curiosity had been satisfied." 95

Ironically, the frequent coastal shipwreck had the capacity to routinely surprise spectators with the unexpected. Like other manifestations of the technological sublime, shipwrecks offered "repeated experiences of awe and wonder, often tinged with an element of terror, which people have had when confronted with particular natural sites, architectural forms, and technological achievements." 96 But unlike the technological sublimes Nye examines, shipwrecks suggested the vulnerability of technology and the impossibility of perpetual "progress." As the New York Times editorialized in the wake of the St. Paul salvage, "In spite of the perfection of her equipment, and of the utmost vigilance of her captain and his aids, she got from out of her course, ran ashore, and was saved from utter wreck only by her own stanchness of construction and by the favoring calm of the weather." ${ }^{97}$ Nothing was to blame. Technology did not fail. The captain, according to this account, did not err. Yet disaster still occurred. What could be done? If nothing could be improved then human mastery of the sea was simply hubris and the notion of human progress was fundamentally flawed.

\footnotetext{
92 "St. Paul Still in the Sand," New York Herald, January 27, 1896.

${ }^{93}$ Nye, Technological Sublime, xiii.

94 "St. Paul Still in the Sand," New York Herald, January 27, 1896.

95 “An Impressive Spectacle,” [Philadelphia] Public Ledger, February 3, 1896.

96 Nye, Technological Sublime, xvi.

97 “The St. Paul Report,” New York Times, February 21, 1896.
} 
Bearing witness to coastal shipwrecks resonated with the widespread, if ambivalent dissatisfaction shared by many late nineteenth-century Americans who, as T.J. Jackson Lears argues, felt "that life had become not only overcivilized but also curiously unreal." 98 This was a complex anti-modern impulse where enthusiasm for material progress coexisted with revulsion for rationalization, bureaucracy, and hubris. So the lure of shipwrecks and salvage was not simple. One observer was half right when he argued that spectators traveled to Long Branch "for the sole purpose of seeing the ship in the sand and with the hope of witnessing her removal." 99 Primed by visual media, literature, and incessant news coverage, spectators repeatedly found shipwrecks compelling events because they combined the fear of seeing the pinnacle of modern technology destroyed with the hope of watching it be saved. More insidiously, shipwreck spectacles conformed to the "pattern of evasive banality" that characterized turn-of-the-century American culture, denying social conflict as they affirmed harmony and progress. ${ }^{100}$ Though composed of rural farmers and urban laborers and sophisticates, the crowds that gazed on the St. Paul were portrayed as a homogenous group of "average citizens" in newspaper articles. ${ }^{101}$

Nevertheless, many "average citizens" travelled to shipwrecks like the St. Paul as part of a broader modern search for authenticity. Well-to-do fin-de-siècle Americans bound in "a weightless culture of material comfort and spiritual blandness" sought intense physical, emotional, and spiritual experiences. Attempts to combat this pervasive sense of unreality, to, as Lears writes, "capture an elusive 'real life' in a culture evaporating into unreality" manifested itself in all parts of American life. Popular literature embraced "life as struggle" narratives, including sea-fights, shipwrecks, and Wild West adventures. Scholars became interested in folk stories for the first time. And a "cult of the real" dominated contemporary theater, cinema, and tourism, particularly disaster tourism. ${ }^{102}$ Shipwrecks, floods, earthquakes, and tornadoes promised undeniably authentic, or real, experiences that were distinct from the elaborately staged spectacles epitomized by New York City's weeklong 1892 Columbian Celebration, Chicago's 1893 World's Fair, and the new amusement parks opening around the country. ${ }^{103}$ Further still, travelling to coastal shipwrecks brought authenticity-anxious spectators from the city- "an emblem of modern unreality" — to an undeniably authentic tourist site — a disaster. ${ }^{104}$

\footnotetext{
${ }^{98}$ T.J. Jackson Lears, No Place of Grace: Antimodernism and the Transformation of American Culture, 1880-1920 (New York: Pantheon Books, 1981), 5.

99 "St. Paul Moved a Short Distance," [Philadelphia] Evening Bulletin, January 29, 1896.

${ }^{100}$ Lears, No Place of Grace, 7-26.

${ }^{101}$ As one local paper wrote: "There appeared to be a peculiar fascination for the average citizen in watching the big boat and the attendant tugs." The Times-Record [Ocean Grove, NJ], February 1, 1896. In all the articles consulted for this article, there are no references to the crises in contemporary America. As Jackson Lears writes about 1896: "The country was aflame with popular movements of the discontented...The streets outside thronged with suffragists, Prohibitionists, Socialists, and Populists." Lears, Rebirth of a Nation, 186.

${ }^{102}$ Emily Godbey, "Disaster Tourism and the Melodrama of Authenticity: Revisiting the 1889 Johnstown Flood," Pennsylvania History 73, no. 3 (2006): 273-315; Lears, No Place of Grace, 32, 103-106.

${ }^{103}$ Godbey, "Disaster Tourism”; David Carletta, "The Triumph of American Spectacle: New York City's 1892 Columbian Celebration," Material Culture 40, no. 1 (2008): 19-40; Lauren Rabinovitz, "Urban Wonderlands: Siting Modernity in Turn-of-the-Century Amusement Parks," in The American Metropolis: Image and Inspiration, ed. Hans Krabbendam et al. (Amsterdam: VU University Press, 2001): 85-97.

${ }^{104}$ Lears, No Place of Grace, 32. Scholars of tourism have demonstrated how this quest for authenticity was destined to fail because tourism inevitably stages authenticity. See for example, Dean MacCannell, The Tourist: A New Theory of the Leisure Class (New York: Schocken Books, 1976); Also, the second set of essays in Shelly Baranowski and Ellen Furlough ed., Being Elsewhere: Tourism, Consumer Culture, and Identity in Modern Europe and North America (Ann Arbor: University of Michigan Press, 2001), which reject conceptions of authenticity as
} 
The late nineteenth-century New Jersey coast remained a foreign place to many Americans. While it was fully incorporated in the modern American state, physically connected to urban centers by railroads and telegraph lines, and culturally relevant to national audiences, the coastthe littoral —was not part of most people's everyday experience (neither were shipwrecks). Spectators who traveled to or read about shipwrecks and salvage were disaster tourists. Many flocked to the scene on trains, carriages, and by foot to gaze upon a sublime scene of destruction (and sometimes death). Once there, tourists took photographs or purchased souvenirs - tangible artifacts - that represented something authentic and real. Armchair disaster tourists read graphic illustrated accounts. To visit and read about shipwrecks and salvage was to mitigate modern anxieties. As journalist Cleveland Moffett wrote in 1901, "Oh, bored folk, idle folk, go to the wreckers, say I, if you want a new sensation, watch the big pontoons, watch the divers, and (if you can) set the crew to telling stories." ${ }^{105}$ Many heeded his advice: the sustained popularity of shipwrecks and salvage during this period suggests that the spectacle fulfilled, if only partially (and temporarily), its promise.

Many tried to participate in the spectacle directly in the spectacle even if they could not chat with the wrecking crews aboard the liner or on the salvage vessels working to save it. People not part of the salvage effort were forbidden to board the St. Paul, although a few enterprising reporters rowed out to the wreck and conducted interviews from a fisherman's dingy. While physically excluded, reporters, spectators, and newspaper readers had unprecedented access to this salvage effort- the St. Paul was the first shipwreck to be connected to the shore by a telephone line. "Anybody," explained the New York Sun, "who is willing to give up the price [of the call], a special one, may indulge in the luxury of ringing up the big ship." It is unclear exactly how man people rang, but every afternoon reporters dialed "125, Long Branch" and were connected to Frederick Reilly, a telephone operator stationed on the St. Paul. Reilly, in his thick French accent, relayed official statements or passed the phone to Captain Jamison or one of the wreckers. ${ }^{106}$ Newspapers offered unprecedented "inside" accounts of the salvage plans and chronicled every activity aboard and around the stranded liner. Reporters captured the anxieties of the salvage effort like never before by highlighting the uncertainty - the authenticity - of the drama off Long Branch.

Armed with a little "insider" knowledge, many in the crowds became active participants on the strand. And why not? They arrived with a clear (if inaccurate) set of ideas gleaned from the ubiquitous presence of the sea, shore, and shipwrecks in American culture. So it is unsurprising that many visitors rather eagerly shared their advice to anyone within earshot. Hours after the initial wreck, crowds "heartily berated" the lifesaving crews for not having it afloat. ${ }^{107}$ Later that week, the Philadelphia Evening Bulletin relayed how, "as is to be expected, every individual has a suggestion or a plan sure to bring satisfactory results if tried. It is positively amusing to hear farmers, merchants and women discuss the problem of how to float a ship. They threw out

having an absolute value and show how tourist promoters and tourists manufactured or altered notions of authenticity to meet shifting and contingent priorities.

${ }^{105}$ Cleveland Moffett, "Careers of Danger and Daring: First Article: The Diver," St. Nicholas 28, no. 3 (1901): 206.

106 "Stranded St. Paul Moves," The Sun [New York], January 27, 1896.

107 “The St. Paul Aground,” New York Tribune, January 26, 1896. 
nautical terms with a recklessness and ignorance that brings the blush to the face of the old salts." 108

Efforts to participate in the St. Paul spectacle extended far beyond the environs of Long Branch. While the liner was aground, thousands of earnest, if naïve, "how to" plans for saving the St. Paul arrived at the offices of the American Line, the wrecking companies, and newspapers across the country. The American Line offices in New York City received letters from as far away as San Francisco by so-called cranks, "people that never saw the ocean and wouldn't know a ground swell from a babbling brook." "109 An ignorance of the sea was reflected in many of their schemes, yet newspapers including the New York Tribune, the Philadelphia Evening Bulletin, and the Baltimore Sun published some of the proposals received in their offices. ${ }^{110}$

As the Bulletin's commentary suggests, many people's efforts to participate in the St. Paul spectacle bordered on the absurd. On the same day it published a plan concocted by a prominent city engineer, the Evening Bulletin offered "a picture, not greatly exaggerated, of daily occurrences at the office of the International Navigation Company" [owner of the St. Paul]. The reporter described the "queer-looking specimens, long-haired, wild-eyed, anxious" cranks and their preposterous schemes, which included mobilizing the entire population of the state of New York, using a giant balloon, dynamiting the sandbar, and using "enormous quantities of oil" to free the St. Paul. In the process, the Bulletin parodied a host of contemporary topics including the length of presidential messages, the size of Patent Office reports, and the verbosity of congressmen, as well as other perennial objects of scorn-medical students, Russian nihilists, and the Irish. ${ }^{111}$ The article, in short, mocked spectators' earnest pursuit of an authentic experience.

Where the Bulletin found satire, others found profit. Entrepreneurs and businessmen commodified the experience of coastal shipwrecks by capitalizing on spectators' search for authenticity. They sold food, transportation, mementoes, and views of the wreck to captive audiences willing (and able) to spend money on an "authentic" encounter. Shipwrecks resonated with many turn-of-the-century Americans because they spoke to ideas and issues that mattered to them. But shipwrecks could only become spectacles when entrepreneurs and businesspeople enabled crowds to mass near shipwrecks. In this way, the physical or sensory experience of shipwreck spectacles - the sounds of the hackman selling rides, the smell of popcorn and chowder stands, the passing glance of the pickpocket searching for a wallet-was embedded in networks of capitalist exchange. Even when people could see the liner was determined by precise timetables set by railroad executives.

For crowds who only "knew" shipwrecks as a sight to see, shipwrecks would only be a spectacle to consume. Yet, even if spectator's experiences were bounded by the dictates of industrial

\footnotetext{
108 "Waiting for the Tide," Evening Bulletin, January 28, 1896.

109 "Chat About Prominent Men," New York Tribune, February 5, 1896. American Line officials and Israel J. Merritt, the leader of the salvage effort, even "talked over" some of the letters they received. Transcript of Record, 132; 909; RG 276; NARA NY.

${ }^{110}$ See for example: "A suggestion for Relief," New York Tribune, January 29, 1896; "The St. Paul Held Fast in the Sand," [Philadelphia] Evening Bulletin, January 30, 1896; "To Float the St. Paul,” [Baltimore] Sun, February 3, 1896.

111 “Cranks' Plans to Move the St. Paul," [Philadelphia] Evening Bulletin, January 30, 1896.
} 
capitalism, shipwrecks spectacles offered "ordinary citizens" opportunities for "authentic" experiences of the sea, shore, and disaster. Like other turn-of-the-century spectacles, shipwrecks could alleviate many anxieties of modern life. ${ }^{112}$ But in their effort to escape the every day, spectators remained consumers. In their effort to encounter something real, something authentic, most spectators watched from a safe distance. But that did not really trouble those who traveled to or read about the St. Paul. Thousands were able to escape the city or their home for a few hours. Many more whiled away an afternoon reading illustrated accounts. It was the search for authenticity, not its attainment, that mattered.

\section{"An Aching Void"}

At 9:20 a.m. on Tuesday, February 4, four wrecking tugs, aided by a strong northeast wind, pulled the St. Paul back into deep water. A relatively small crowd of lifesaving men, baymen, and local residents, braved the cold, inclement weather to watch the tugs cast off their lines. The liner departed Long Branch ten days after it wrecked, steaming northeast through sleet and snow squalls, before bearing west after Sandy Hook and worked through a bustling New York Harbor to its berth off Fulton Street. According to the New York Tribune, only as it began to dock did nearby vessels give "the pride of the American Line a proud welcome." 113

News of the successful salvage spread rapidly, and the spectacle continued, if only for another few days. Half an hour after word of the liner's release reached Philadelphia, "everybody seemed to know it. People who had never been on a steamship in their lives could be heard congratulating each other as though they owned the St. Paul." ${ }^{114}$ Articles appeared in afternoon dailies across the country. Over the next two days, papers in Chicago, Minneapolis, New Haven, Santa Fe, and San Francisco as well as New York, Philadelphia, Boston, and London carried headlines of the wreckers' success. ${ }^{115}$

In Long Branch, diarist William Maps noted the "great rejoicing on the arrival [of the St. Paul] in New York" but he neglected to describe the mood closer to home. ${ }^{116}$ The summer resort had lost its winter draw. As one reporter put it, the spectacle had "brought a mint of money to Long Branch and leaves behind her an aching void."117 The crowds did not return that winter. Businessmen boarded up their hotels and restaurants for the second time that winter. Hackmen no longer offered rides to see "the wreck," and the fishermen went back to fishing. In Philadelphia, Dumont's "The St. Paul in the Sand; or, Stuck in Jersey” ran through the end of

\footnotetext{
${ }^{112}$ Wood, Lynching Spectacle, 13.

113 "In Her Element Again," New York Tribune, February 5, 1896; "The St. Paul is Floated off the Bar," [Philadelphia] Evening Bulletin, February 4, 1896; Transcript of Record, 66-67; 909; RG 276; NARA NY.

114 "The News in the City," [Philadelphia] Evening Bulletin, February 4, 1896; "The St. Paul is Floated off the Bar," [Philadelphia] Evening Bulletin, February 4, 1896.

115 “St. Paul is Afloat," [Chicago] Inter Ocean, February 5, 1896; “The St. Paul is Afloat," Minneapolis Journal, February 4, 1896; "The St. Paul Floated," New Haven Register, February 4, 1896; "Steamer St. Paul Safe," [Santa Fe] New Mexican, February 4, 1896; "St. Paul Once More Sails the Ocean," Philadelphia Inquirer, February 5, 1896; "St. Paul Safely Floated," New York Times, February 4, 1896; "Released from Long Branch," The San Francisco Call, February 5, 1896; "Floating of the St. Paul," The Standard [London], February 5, 1896.

${ }^{116}$ William Russel Maps Diary, February 5, 1896; William Russel Maps Papers, Collection 212; Monmouth County Historical Association.

117 “St. Paul Gets Off,” New York Herald, February 5, 1896.
} 
February until it was replaced by a more contemporary skit. ${ }^{118}$ Traces of the St. Paul rapidly vanished from the landscape.

Still, the attenuated spectacle continued in newspapers as the investigation, repairs, and salvage case ran its course. The marine underwriters began their investigation the day after the St. Paul docked in New York. A federal investigation by the Steamboat Inspection Service commenced the following week. The underwriters' final report was never published, but the St. Paul was apparently declared safe for service; after minor repairs in Newport News, Virginia, it was crossing the Atlantic again by the end of the month. ${ }^{119}$ The federal inquiry exonerated Captain Jamison, finding that he "was not unskillful in the navigation of his ship or negligent of his duty." ${ }^{120}$ The flurry of editorials about this decision effectively concluded the spectacle, even if the legal consequences of the wreck had yet to run their course. The St. Paul's salvage case appeared in the US District Court in the Southern District of New York in May 1897. By the time the final decision was handing down by the Circuit Court of Appeals in April 1898, interest in the St. Paul's accident had virtually disappeared. A small blurb hidden deep in a few newspapers was all the coverage the decision warranted. ${ }^{121}$ Few could be negative for long about this symbol of American industry and maritime success.

The St. Paul's successful salvage made it an "icon of American greatness." ${ }^{122}$ Editorialists lauded every American person, business, or institution connected to the rescue. Commentators praised the perseverance of the St. Paul's owners, the assistance of the federal Weather Bureau, and the skill of American seamanship and shipbuilding. ${ }^{123}$ The New York Tribune marveled at the wreckers who "went on coolly and calmly to apply methods which had been thoroughly tested by experience, and the result is a marked triumph for skill and sagacity." ${ }^{124}$ Five days after the St. Paul left Long Branch, the Tribune published "The Trade of the Wrecker," an article describing "an industry about which comparatively little is known by the general public." Interest in marine salvage, piqued by the St. Paul's successful salvage, merited an exposition on the "great skill and ingenuity displayed by [the] expert hands" of the wreckers. ${ }^{125}$ With successful salvage, American skill, technology, and temperament remained triumphant.

A closer inspection, however, reveals an ambiguous antimodernism lurked in this sea of praise. Commentators latched onto the Steamboat Inspection Service's investigation report because, as

\footnotetext{
118 “Eleventh Street Opera House,” Philadelphia Inquirer, February 18, 1896.

119 “St. Paul will Sail Wednesday,” New York Times, February 20, 1896.

120 “Capt. Jamison Exonerated," New York Times, February 20, 1896.

121 “St. Paul Safely Floated,” New York Times, February 5, 1896; “The Stranding of the St. Paul,” New York Times, February 9, 1896; "The St. Paul Report," New York Tribune, February 11, 1896; "St. Paul in Newport News," New York Tribune, February 12, 1896. The New York Time's coverage of the salvage is representative: "Steamship St. Paul Libelled," New York Times, June, 12, 1896; "Salvage for the St. Paul," New York Times, July 25, 1897; "Large Salvage on St. Paul," New York Times, April 24, 1898.

${ }^{122}$ As David Nye argues: "The popular sublime became part of the emergent cultural nationalism of the United States in the nineteenth century. The American public celebrated the fact that a spectacular sight was the biggest waterfall, the longest railway bridge, or the grandest canyon, and they did so with a touch of pride that Europe boasted no such wonders. Natural places and great public works became icons of America's greatness." Nye, Technological Sublime, 32.

123 "In Her Element Again” and “The St. Paul Saved,” New York Tribune, February 5, 1896.

${ }^{124}$ Editorial, New York Tribune, February 5, 1896.

125 "The Trade of the Wrecker," New York Tribune, February 9, 2009.
} 
the New York Tribune concluded, it led to "mingled feelings of satisfaction and uneasiness." Satisfaction that one of the nation's most respected mariners, Captain Jamison, was "vindicated." Unease because if nothing could be blamed, how could it be fixed? What could be done to prevent a repetition of such a disaster "by any other ship on any other voyage?" 126 Even in the Scientific American, a bastion of modernist thought, traces of ambiguity and doubt remained:

The seagoing steamship embodies some of the greatest triumphs of modern engineering and science. Yet in spite of this the unavoidable weaknesses and imperfections of the service go to prove how well founded was man's dread of the sea... The fact that the captain of the St. Paul, which went ashore on the beach at Long Branch, was exonerated from all blame shows that man has not yet achieved his mastery over the sea with its concomitants of fogs, gales and ocean currents. ${ }^{127}$

Shipwrecks were profoundly unsettling because they embodied the limits or shortcomings of the modern project. If modernity, as Kevin Rozario suggests, can be characterized as the quest to make the world safer, shipwrecks were almost-daily reminders of the "catastrophic logic of modernity" - that the modern project to make the world more secure was underwritten by unremitting destruction and disaster. ${ }^{128}$ To witness a shipwreck was to encounter this fundamental paradox.

Still, it was a passing (if not subconscious) concern. Most commentators treated the St. Paul how they treated any other shipwreck. As one commentator concluded: "The incident will not cause a panic, nor anything like it. It will not deter a single traveler...nor shake the faith of the public in the seamanship of Yankee skippers and the staunchness of Yankee ships.” The St. Paul, they argued, should stimulate efforts to find ways of preventing similar disasters in the future to "make any repetition of the St. Paul's misshape, humanly speaking, impossible." ${ }^{129}$ Nothing to linger over, the St. Paul should inspire Yankee ingenuity to once-and-for-all conquer the sea. The millennialist vision of America's future remained strong.

While the sea has yet to be subdued, the St. Paul shipwreck quickly faded from popular memory. Hours after it docked in New York, editors of the Philadelphia Evening Bulletin brushed aside concerns as "nonsense and superstition!" that the liner would be marked as a "Jonah," an unlucky vessel. They continued: "Besides, these things are easily forgotten." 130 The Bulletin's prognostication proved correct. The St. Paul soon returned to racing the British liner Campania. By the end of 1896, the New York Tribune considered a race between the two "the habit of the ocean greyhounds ... whenever they sight each other." ${ }^{131}$ Editorial pages that had denounced Captain Jamison's racing as irresponsible in January and February praised it months later for proving America's maritime prowess. Risks brought rewards. Regarding one particularly quick trip four months after the wreck that included an eerily reminiscent high-speed run into a New York Bay blanketed in fog, the New York Times praised the St. Paul for a "great performance"

\footnotetext{
126 “The St. Paul Report,” New York Tribune, February 20, 1896.

127 "Modern Steamships and Navigation," Scientific American, May 9, 1896, 290.

${ }^{128}$ Rozario, Culture of Calamity, 9.

129 “The St. Paul Report,” New York Tribune, February 20, 1896.

130 "Off at Last," [Philadelphia] Evening Bulletin, February 4, 1896.

${ }^{131}$ A Campania-St. Paul Race," New York Tribune, December 5, 1896.
} 
against its technically superior British-built rival. ${ }^{132}$ "Which Will be the Winner," a dramatic two-page illustration published the following week in Leslie's Weekly, depicted the two liners racing in a tempestuous Atlantic. ${ }^{133}$ Neither description referenced the accident off Long Branch.

The speed at which the St. Paul stranding was forgotten suggests the frequency of coastal shipwrecks and seaside spectacles. As daily occurrences along much of the American coastline for decades after the Civil War, shipwrecks often became spectacles. Businesses and entrepreneurs commodified the experience of shipwrecks and salvage by tapping into the popularity of technology and the maritime world and exploiting an "authentic" experience. Spectators on the beach, like readers in their homes, found a momentary escape from a tumultuous present. But only in the modern, integrated littoral could coastal shipwrecks become commercialized spectacles. Shipwrecks and the disaster tourism that accompanied them reinforced narratives of technological progress and American exceptionalism even as they symbolized the spectacular, if ephemeral, possibilities of everyday life.

132 "The St. Paul," New York Times, June 28, 1896.

133 "Which Will be the Winner," Leslie's Weekly, July 9, 1896. 